Arquero, J. L., del Barrio-García, S., \& Romero-Frías, E. (2016). What Drives Students' Loyalty-Formation in Social Media Learning Within a Personal Learning Environment Approach? The Moderating Role of Need for Cognition. Journal of Educational Computing Research, Volume: 55 issue: 4, page(s): 495-525

https://doi.org/10.1177/0735633116672056 Preprint for research purposes.

Please refer to the journal's page for the final version of the paper

\title{
What drives students' loyalty-formation in social media learning within a personal learning environment approach? The moderating role of need for cognition
}

\author{
José L. Arquero ${ }^{1}$, Salvador del Barrio-García ${ }^{2}$, and Esteban Romero-Frías ${ }^{3 *}$ \\ ${ }^{1}$ Universidad de Granada, Departamento de Comercialización e Investigación de \\ Mercados, Granada, Spain $/ /{ }^{2}$ Universidad de Sevilla, Departamento de Contabilidad, \\ Sevilla, Spain $/ /{ }^{3}$ Universidad de Granada, Medialab UGR \& Departamento de \\ Economía Financiera y Contabilidad, Granada, Spain
}

*Corresponding author: erf@ugr.es

\section{$\underline{\text { Short bios }}$}

José Luis Arquero is an Associate Professor of Accounting at University of Sevilla. After obtaining the extraordinary doctoral award of the University of Sevilla with a thesis focused in accounting education, he has published several papers in this area in specific journals, but also in education and psychology journals (such as Innovations in Education and Teaching International, Education \& Training, Journal of Vocational Education \& Training or Journal of Educational Technology \& Society). He is the Editor of the Spanish Journal of Accounting, Finance and Management Education.

Salvador Del Barrio-García is an Associate Professor of Marketing at University of Granada. His areas of specialization are the Integrated Marketing Communication (IMC), online consumer behavior and marketing for Higher Education. He has also published various peer-reviewed papers in prestigious journals such as Journal of Educational Technology \& Society, International Journal of Advertising, Journal of Advertising Research, European Journal of Marketing, among others. He is referee for several peer-reviewed journals. He is the Associate Editor of the European Journal of Management and Business Economics.

Esteban Romero-Frías is an Associate Professor of Finance and Accounting at University of Granada. His areas of specialization are Webometrics, Education and Digital Culture. Director of Medialab UGR Research Laboratory for Digital Culture and Society (http://medialab.ugr.es/). He has published papers in journals such as Scientometrics, Journal of Information Science and Journal of Educational Technology \& Society. More information at: http://estebanromero.com/

\section{Keywords}

Student loyalty; learning satisfaction; personal learning environment; social media learning; need for cognition. 


\section{Abstract}

Our study analyzes an educational experience based on the integrated use of social media within a higher education course under a personal learning environment (PLE) approach, and investigates the factors that determine students' loyalty to social media learning. We examined the moderating role of need for cognition (NFC) in students' formation of attitudes, satisfaction and loyalty toward this learning experience.

The results indicate that NFC has an influence on these variables, significantly moderating how loyalty toward social media learning is formed. For high-NFC students, satisfaction with the learning experience is the most important variable to explain loyalty; whereas for low-NFC students, attitudes have a stronger effect.

Different strategies are suggested, according to the learners' NFC levels, for increasing the use of social media in PLEs. Practical implications for improving the integration of such informal resources into formal education are discussed.

\section{Introduction}

The last two decades have witnessed a significant increase in the development of innovative approaches to education using information and communication technologies (ICT) (Lee, 2010). Since the emergence of Web 2.0 (O'Reilly, 2005), social media have dominated trends in the use of digital technology around the world and have become extremely popular particularly among new generations of students. In a recent report, the Pew Research Center (Perrin, 2015) reviewed the adoption of digital technology in the USA from 2005 to the present day, finding that $65 \%$ of the entire American population now uses social networking sites, in contrast with just $7 \%$ in 2005 . And among young adults (aged 18 to 29) the figure currently stands at 90\%. The situation in Spain, where the present study takes place, follows the same pattern. According to the national media survey (EGM) published by the Spanish Association for Communication Media Research (AIMC) for the period October-November 2014, 62.6\% of the population accessed the Internet at least once every day, and over $85 \%$ had accessed a social network during the previous week. 
Arquero, J. L., del Barrio-García, S., \& Romero-Frías, E. (2016). What Drives Students' Loyalty-Formation in Social Media Learning Within a Personal Learning Environment Approach? The Moderating Role of Need for Cognition. Journal of Educational Computing Research, Volume: 55 issue: 4, page(s): 495-525

https://doi.org/10.1177/0735633116672056 Preprint for research purposes.

Please refer to the journal's page for the final version of the paper

In the European context, the European Commission (2012) highlighted the opportunities that technology offers for improving quality, access and equity in education, and called for greater digital competence among students of all ages. In this line, social media undoubtedly generate new opportunities to engage students in higher education (Romero-Frías, \& Arquero, 2013; Selwyn, 2007; Tess, 2013) as they are remarkably effective at connecting people and facilitating the exchange of information. Moreover, according to the literature (Ajjan, \& Hartshorne, 2008; Mason, 2006; Selwyn, 2007, 2012), social media services support educational activities by facilitating interaction, collaboration, creativity, active participation, information- and resource-sharing and critical thinking context.

The strategic position of ICT in European education policy, the high level of usage of social media among students (Perrin, 2015) and the advantages of their use in education require the integration of these technologies into learning programs in order to increase students' digital competence and engagement with the academic experience. In turn, this integration requires an understanding of the students' experience in order to increase their satisfaction and loyalty to the use of ICT in their learning processes.

The success of any educational use of social media depends upon the reactions and acceptance of users toward these media, and the ability to generate loyalty among students such that they use the available resources and recommend their use. The formation of loyalty toward a product, a service or an experience depends on two main antecedents: firstly, user satisfaction generated after a positive experience (Bailey, \& Pearson, 1983; Ives, Olson, \& Baroudi, 1983; Melone, 1990); and secondly, positive attitudes of the user toward the experience, as emphasized in robust theories such as the theory of planned behavior (Ajzen, 1991) or the technology acceptance model (TAM) (Davis, Bagozzi, \& Warshaw, 1989).

Additionally, given that social media open up the students' learning environment to numerous information resources and relations with other people, need for cognition (NFC) (Cacioppo, \& Petty, 1982) could play a determining role in students' loyaltyformation. NFC refers to the need to structure relevant situations in meaningful and 
Arquero, J. L., del Barrio-García, S., \& Romero-Frías, E. (2016). What Drives Students' Loyalty-Formation in Social Media Learning Within a Personal Learning Environment Approach? The Moderating Role of Need for Cognition. Journal of Educational Computing Research, Volume: 55 issue: 4, page(s): 495-525

https://doi.org/10.1177/0735633116672056 Preprint for research purposes.

Please refer to the journal's page for the final version of the paper

integrated ways (Cohen, Stotland, \& Wolfe, 1955), and is linked to external information-search behavior in both offline (Verplanken, 1993) and online contexts (Das et al., 2003). The role of NFC as a moderating variable helps us understand how different types of students adopt social media for learning purposes.

Our study reports an educational experience based on the integration of social media tools into a higher education course under a personal learning environment (PLE) approach. We refer to this particular approach as 'social media learning'. The importance of analyzing social media for education, instead of traditional Learning Management Systems (LMS) specially designed for education, is that social media already constitutes a part of the informational environment of students and therefore its educational success is not so dependent on the formal context as when using tools that do not have any other social use in their lives. The study investigates the factors that determine students' loyalty to social media learning, as a means of improving the effective adoption of ICT in higher education and particularly in the informal learning practices that in the future could support their lifelong learning. The originality of this study lies in the type of educational experience under study and its examination of the moderating role of NFC in users' formation of attitudes, satisfaction and loyalty toward this learning experience.

\section{Theoretical background, development of hypotheses and research model}

\subsection{Social media in higher education and personal learning environments}

Following Dabbagh, and Kitsantas (2012, p. 3) we define social media as 'a variety of networked tools or technologies that emphasize the social aspects of the Internet as a channel for communication, collaboration, and creative expression [that] is often interchangeable with the terms Web 2.0 and social software'. Many works have pointed to the positive impact of social media on education (e.g. Richardson, 2009; Selwyn, 2012; Solomon, \& Schrum, 2007). For instance, Redecker et al. (2010) considered social networking sites to be effective at developing essential skills (selecting relevant information, critically interpreting and analyzing the socio-cultural context, working collaboratively, sharing knowledge, etc.). Arquero, and Romero-Frías (2013) highlighted that social constructivism is regarded by some as a way to interpret and assess some of the potential benefits of social media in education. 
Arquero, J. L., del Barrio-García, S., \& Romero-Frías, E. (2016). What Drives Students' Loyalty-Formation in Social Media Learning Within a Personal Learning Environment Approach? The Moderating Role of Need for Cognition. Journal of Educational Computing Research, Volume: 55 issue: 4, page(s): 495-525

https://doi.org/10.1177/0735633116672056 Preprint for research purposes.

Please refer to the journal's page for the final version of the paper

The experience under study integrates different social media within the conceptual approach of PLE (Attwell, 2007; Castañeda, \& Adell, 2013). PLE is a concept that refers to the set of tools, devices, connections and networks that people use to learn (Romero-Frías, \& Arquero, 2013). According to the EDUCAUSE Learning Initiative (2009, p. 1) a PLE is defined as the set of 'tools, communities, and services that constitute the individual educational platforms that learners use to direct their own learning and pursue educational goals'. Nowadays many of these tools are based on social software- that is, software that is specially designed for social collaboration. Attwell (2007, p. 1) refers to PLE as a 'new approach to using technologies for learning'.

Unlike LMS, closed platforms particularly designed for instruction such as Moodle or Blackboard, a PLE represents an ecosystem of strategies, relations and tools that is created and managed autonomously by students to match their own learning needs. Therefore, the development of a PLE using social media allows students to engage with the real-world context by exploring services that could be re-used for personal and professional purposes after the end of the formal education period (Attwell, 2007). Similarly, the use of social media in higher education allows informal education to be incorporated into formal settings as a way to foster lifelong learning (Bull et al., 2008; Dabbagh, \& Kitsantas, 2012; Meyers, Erickson, \& Small, 2013). Given this advantage, some experts (Dabbagh, \& Reo, 2011; McGloughlin, \& Lee, 2010; Selwyn, 2007) consider that universities should integrate social media into their learning programs to facilitate the creation of PLEs that support more learner-centered education systems.

Despite the call for an increased use of social media in educational settings, there is still a research gap in relation to the use of social media within a PLE approach and the formation of associated attitudes and loyalty. There is literature, however, focusing in the acceptance of LMS by students (e.g. Ngai, Poon, \& Chan, 2007; Liu, Liao, \& Pratt, 2009; Arteaga, \& Duarte, 2010; Sanchez-Franco, 2010; Liu et al., 2010). 
Arquero, J. L., del Barrio-García, S., \& Romero-Frías, E. (2016). What Drives Students' Loyalty-Formation in Social Media Learning Within a Personal Learning Environment Approach? The Moderating Role of Need for Cognition. Journal of Educational Computing Research, Volume: 55 issue: 4, page(s): 495-525

https://doi.org/10.1177/0735633116672056 Preprint for research purposes.

Please refer to the journal's page for the final version of the paper

\subsection{Student attitudes and loyalty-formation. The mediating role of learning satisfaction}

Loyalty is a construct widely used in the literature across many areas, particularly in management studies. According to Dick, and Basu (1994), loyalty is the relation between the attitude towards a brand or service and its repeated purchase; and is defined by Jones, and Sasser (1995) as the feeling of attachment to, or affection for, a company's people, products or services. It has been found that loyal customers are more likely to recommend products and services to friends and other potential customers, giving rise to a positive word-of-mouth process (Shoemaker, \& Lewis, 1999).

Han, and Ryu (2009) highlighted the multidimensional nature of the construct, which encompasses user attitudes focused on perceptions, evaluations and feelings. Many authors consider attitudes to be the most important antecedent of loyalty (Bowen, \& Chen 2001; Han, \& Ryu, 2009) ${ }^{1}$. Although student loyalty has been researched in higher education contexts, the focus to date has been on loyalty toward the institution (Ali et al., 2016; Annamdevula, \& Bellamkonda, 2016; Hennig-Thurau, Langer, \& Hansen, 2001; Helgesen, \& Nesset, 2007a; Sultan, \& Wong, 2014; Wong, 2016) rather than to a particular educational experience or technology such as social networking sites (Ku, Chen, \& Zhang, 2013; Lin, Fan, \& Chau, 2014; Park, 2014; Xu, Ryan, Prybutok, \& Wen, 2012).

In our study, loyalty has a relevant role to understand the future impact of social media in learning situations. Given the general purpose of these media and the control that students exert over them, the more loyal they are to their use for learning the more chances we have to generate a personal learning environment that might be used in future learning situations with independence of the specific setting. The use of social media for learning may empower students to control their own learning in many different situations, from a formal education context (as reported in this study) to informal education contexts to which they will be exposed to in their personal and professional lives.

\footnotetext{
${ }^{1}$ The role of attitudes as an antecedent of loyalty is widely supported by many studies and theories, such as the theory of reasoned action (Fishbein, \& Ajzen, 1975), the theory of planned behaviour (Ajzen, 1991) and the technology acceptance model (TAM) (Davis, Bagozzi, \& Warshaw, 1989).
} 
Arquero, J. L., del Barrio-García, S., \& Romero-Frías, E. (2016). What Drives Students' Loyalty-Formation in Social Media Learning Within a Personal Learning Environment Approach? The Moderating Role of Need for Cognition. Journal of Educational Computing Research, Volume: 55 issue: 4, page(s): 495-525

https://doi.org/10.1177/0735633116672056 Preprint for research purposes.

Please refer to the journal's page for the final version of the paper

Based on these premises, this research proposes the following hypothesis:

H1. Students' attitude toward social media usage is positively related to their loyalty toward social media.

Satisfaction can be defined in various ways (Giese, \& Cote, 2000). According to Mano, and Oliver (1993), it refers to an evaluative, affective or emotional response provoked by the experience a consumer has with a product or service. It results from the comparison between perceptions of a product or service, once consumed, and prior expectations (Hunt, 1977).

Satisfaction has been studied as a mediator in the processing of online information (Casaló, Flaviánand Guinalíu, 2008a, 2008b; Castañeda, Rodríguez, \& Luque, 2009; Szymanski, \& Hise, 2000) and also as a determinant of success and usage of ICT (Bailey, \& Pearson, 1983; Bhattacherjee, 2001a, 2001b; Hayashi et al., 2004; Lin, Wu, $\&$ Tsai, 2005). In this regard, dissatisfaction would lead to a decrease in the intention to purchase (Evanschitzky, \& Wunderlich, 2006) or, in our case, in the intention to repeat this learning experience in the future. Numerous studies indicate that satisfaction is positively associated with behavioral intention and with the inclination to recommend (Cronin, \& Taylor, 1992; Gotlieb, Grewal, \& Brown, 1994; Gupta, \& Stewart, 1996; Tam 2000; Petrick, 2004) and, therefore, with loyalty-formation.

The equivalent concept in education (learning satisfaction or student satisfaction) can be defined as a student's overall positive assessment of his or her learning experience (Keller, 1983). Elliot, and Healy (2001) indicated that satisfaction is a short-term attitude that results from the evaluation of a student's experience with the education service received. Learning satisfaction is thought to be positively related to students' loyalty (Athiyaman, 1997; Schertzer, \& Schertzer, 2004; Marzo-Navarro, PedrajaIglesias, \& Rivera-Torres, 2005; Helgesen, \& Nesset, 2007a). 
Arquero, J. L., del Barrio-García, S., \& Romero-Frías, E. (2016). What Drives Students' Loyalty-Formation in Social Media Learning Within a Personal Learning Environment Approach? The Moderating Role of Need for Cognition. Journal of Educational Computing Research, Volume: 55 issue: 4, page(s): 495-525

https://doi.org/10.1177/0735633116672056 Preprint for research purposes.

Please refer to the journal's page for the final version of the paper

Regarding the use of technologies for educational purposes, Roca, Chiuband Martínez (2006) and Shu-Sheng, and Hsiu-Mei (2011) found a significant relationship between learning satisfaction and the intention to continue using e-learning.

Therefore, we propose the following hypothesis:

H2. Student satisfaction with social media is positively related to student loyalty toward social media.

Many studies have demonstrated the role of attitudes as an antecedent of satisfactionformation in different areas of knowledge. For example, Lim, Benbasat, and Ward (2000) found that overall perceptions of a profession influence the satisfaction felt when exercising it - that is, employees that perceived their profession to be prestigious showed a high level of job satisfaction. Other studies have observed that overall attitude toward a brand has a strong influence on customer satisfaction (Andreassen, \& Lindestad, 1998; Hildebrandt, 1998; Mazursky, \& Jacoby, 1986). Ekinci, and Riley (2003) argued that satisfaction is influenced by pre-purchase attitudes. In higher education contexts, Ozkan, and Koseler (2009) highlighted the importance of understanding and identifying the attitudes of learners toward the LMS when investigating their satisfaction.

Therefore, we formulate the following hypothesis:

H3. Student attitude toward social media is positively related to student satisfaction with social media.

\subsection{The role of need for cognition}

Evans, Kirby, and Fabrigar (2003) highlighted that educational researchers have naturally been interested in how students learn and process information within the academic context. The concept of NFC, which appeared for the first time in the work of Cohen, Scotland, and Wolfe (1955), is an attempt to conceptualize this process. These authors described NFC as the need to structure relevant situations in meaningful, integrated ways - where 'need' is used in the sense of a likelihood or tendency, rather 
Arquero, J. L., del Barrio-García, S., \& Romero-Frías, E. (2016). What Drives Students' Loyalty-Formation in Social Media Learning Within a Personal Learning Environment Approach? The Moderating Role of Need for Cognition. Journal of Educational Computing Research, Volume: 55 issue: 4, page(s): 495-525

https://doi.org/10.1177/0735633116672056 Preprint for research purposes.

Please refer to the journal's page for the final version of the paper

than in a biological sense (Evans, Kirby, \& Fabrigar, 2003). Given the strong relationship between NFC and motivation, Petty, and Cacioppo (1981) introduced NFC in their elaboration likelihood model (ELM) as a relevant moderator in information processing. In a later paper, they used this concept (Cacioppo, \& Petty, 1982) when investigating differences between individuals in their tendency to engage in, and enjoy, thinking.

High_NFC individuals (cognizers) tend to seek, acquire, think about and reflect back on information to make sense of stimuli and events, producing a more stable cognitive change. By contrast, low_NFC individuals (cognitive misers) are more likely to rely on others (such as celebrities and experts), cognitive heuristics, secondary stimuli or social comparison processes to acquire meaning (Cacioppo et al., 1996; Evans, Kirby, \& Fabrigar, 2003), thereby producing a temporary, unstable or unpredictable cognitive change. Therefore, to some extent this variable determines the ability and desire to make a cognitive effort (Zhang, \& Buda, 1999). It has also been related to learning approaches, mainly high levels of NFC with deep approaches (Evans, Kirby, \& Fabrigar, 2003) and to growth goals, defined as the desire to understand one's environment and to develop the skills necessary to affect the environment to meet the higher-level self-goals (DeShon, \& Gillespie, 2005).

Since the initial development of NFC, it has been extensively studied in a variety of contexts (Cacioppo et al., 1996; Close, Lacey, \& Cornwell, 2015; Hill et al., 2013; Sicilia, Ruiz, \& Munuera, 2005; Wu, Parker, \& De Jong, 2014). Nevertheless, there are very few studies analyzing the effects of NFC in the use of social media. People who are intrinsically interested in analyzing and processing information (high_NFC) may be more likely to form positive attitudes, and thus behavioral intention, toward using social media, bearing in mind that such websites provide access to high volumes of information. In contrast, people who are more attracted to the design of a website than to the content (low_NFC) may process messages differently and thus form their attitude toward social media by linking them with peripheral cues (Gangadharbatla, 2008). Gangadharbatla (2008) found that students' NFC level was positively related to attitude and intention to use Facebook. Hughes et al. (2012) found that the level of NFC was 
Arquero, J. L., del Barrio-García, S., \& Romero-Frías, E. (2016). What Drives Students' Loyalty-Formation in Social Media Learning Within a Personal Learning Environment Approach? The Moderating Role of Need for Cognition. Journal of Educational Computing Research, Volume: 55 issue: 4, page(s): 495-525

https://doi.org/10.1177/0735633116672056 Preprint for research purposes.

Please refer to the journal's page for the final version of the paper

connected to the use of social networking sites as an information source but not necessarily for social use. More specifically, they found that those who access Twitter for informational purposes are doing so for its utilitarian value and cognitive stimulation.

Although there is relevant literature examining the role of NFC in the context of acceptance in e-learning (Chen, \& Wu, 2012; Del Barrio-García, Arquero, \& RomeroFrías, 2015; Evans, Kirby, \& Fabrigar, 2003; Kühl, Eitel, Damnik, \& Körndle, 2014; Turner, \& Croucher, 2013; Kai-Wen, 2011), to our knowledge no previous research has investigated the moderating role of NFC in the loyalty-formation process of students toward the use of social media within a PLE approach in higher education.

Therefore, we formulate the following hypothesis:

H4. NFC moderates students' loyalty-formation toward social media learning.

Figure 1 depicts the four hypothesis based on the literature review and presents a theoretical model to understand the formation of student loyalty in using social media learning. Student satisfaction is considered a mediating variable between the students' attitude toward using social media and their loyalty.

-Insert Figure 1 here-

Based on the results of Gangadharbatla (2008), and in the context of the effect of NFC on the main variables of the model, we propose the following hypothesis:

H5. There are differences in the main variables of the model (attitudes, learning satisfaction, student loyalty, behavioral intention to use and willingness to recommend) that are attributable to student NFC levels.

\section{Methodology}

\subsection{Sample and context}

The sample comprised 202 students taking an elective subject on a Business and Administration Degree at the University of Granada (Spain). By gender, the composition of the sample was $31 \%$ male and $69 \%$ female. The subjects were aged between 20 and 43 years old, with a mean of 23 . 
Arquero, J. L., del Barrio-García, S., \& Romero-Frías, E. (2016). What Drives Students' Loyalty-Formation in Social Media Learning Within a Personal Learning Environment Approach? The Moderating Role of Need for Cognition. Journal of Educational Computing Research, Volume: 55 issue: 4, page(s): 495-525

https://doi.org/10.1177/0735633116672056 Preprint for research purposes.

Please refer to the journal's page for the final version of the paper

The data were gathered through a Web-based questionnaire using the service Surveymonkey at the end of the course, before the final grades were communicated to students in order to avoid bias in their responses.

A typical concern in such surveys is that information collected from respondents might have a problem of common method variance. We attempted to control this problem by means of procedural and statistical techniques. Following the recommendations by Podsakoff et al. (2003), we initially addressed the minimization of common method variance via research design. First, the survey began with a brief introduction explaining the main objectives without suggesting any relationship between variables. Second, the survey indicated that all responses were confidential and only to be treated for research purposes at an aggregated level. Third, we emphasized that respondents should answer the survey questions as honestly as possible, that there were no correct or incorrect answers and that the information provided would not have any impact on the course assessment. In terms of good statistical procedure, and in order to prevent any possible bias among the respondents, the Harman's single factor test (McFarlin and Sweeny, 1992) was applied to all the relevant variables in the model, using the 'eigenvalue greater than one' criterion. This in fact revealed three factors as opposed to just one. To guarantee absence of bias, the results must show a low fit of the estimated factors. The results of this combination of procedures and statistical tests suggest that the common method bias in the data was relatively limited (Podsakoff et al., 2003).

As mentioned earlier, the pedagogical approach, based on social constructivism, was operationalized through the concept of the PLE (Chatti, Jarke, \& Specht, 2011; Häkkinen, \& Hämäläinen, 2011; Romero-Frías, \& Arquero, 2013; Tu, SujoMontes et al., 2012; Wilson et al., 2009). A PLE is a personal set of resources used by individuals to pursue their own learning objectives. To create the PLE for our study we proposed a combination of digital tools that were already used by the majority of students (Facebook or Twitter) with others that, although known by most of them, were not so frequently used (blogs or wikis). This approach was more straightforward to implement than adapting the entire course design to a new set of tools. Furthermore, the 
Arquero, J. L., del Barrio-García, S., \& Romero-Frías, E. (2016). What Drives Students' Loyalty-Formation in Social Media Learning Within a Personal Learning Environment Approach? The Moderating Role of Need for Cognition. Journal of Educational Computing Research, Volume: 55 issue: 4, page(s): 495-525

https://doi.org/10.1177/0735633116672056 Preprint for research purposes.

Please refer to the journal's page for the final version of the paper

students continued to use their existing profiles if they already had presence in the different services (for example, those with a Twitter account or blog were not required to create new ones). The objective was to help them develop their academic and professional presence in social networking sites that were already employed by them for social purposes and to present them with new tools with the potential to improve lifelong learning.

Instructional sessions were carried out at the beginning of the course to present the PLE concept and before each activity to teach the students the basics of the different tools. The social media services that, together, formed the suggested PLE for the course in question and the corresponding activities were as follows:

- Facebook. A closed group was created to communicate and coordinate activities on the course. The students were instructed to publish freely, not only about the topic under study but about any particular interest they would like to share. No moderation policy was applied. The purpose was to create a learning community where informal learning could emerge alongside the course content. In addition, the group was used by the teacher to distribute messages concerning the course. The activities carried out via Facebook had no bearing on marks.

- Twitter. Twitter was used as a network for informal liaison between students, and between the students and the teacher. A hashtag was established to publish messages related to the course. For example, Twitter was used in class to revise and summarize the main content of the syllabus in order to prepare for the final exam (again, no bearing on marks).

Blogs. Personal blogs were maintained by the students to generate and publish content from a critical point of view. Different activities were undertaken and assessed in this format (accounting for $30 \%$ of the final mark awarded for the elective course), for example: writing a critical post about business issues, producing an analysis of a text on financial reporting or reflecting on their own PLE. 
Arquero, J. L., del Barrio-García, S., \& Romero-Frías, E. (2016). What Drives Students' Loyalty-Formation in Social Media Learning Within a Personal Learning Environment Approach? The Moderating Role of Need for Cognition. Journal of Educational Computing Research, Volume: 55 issue: 4, page(s): 495-525

https://doi.org/10.1177/0735633116672056 Preprint for research purposes.

Please refer to the journal's page for the final version of the paper

- Wiki. An open business encyclopedia that replicates the Wikipedia model was used during the course (Descuadrando - http://descuadrando.com). Students were tasked with creating encyclopedic-style entries (20\% of the final mark).

In addition to these activities, the students sat a final exam (50\% of the final mark).

The learning environment approach that we study justifies the use of a set of tools that offer complementary functions and opportunities to develop different competences. By contrast to LMS, where all the functions needed in a course are concentrated in a single platform, the PLE approach is based in a distributed model. This approach adds more complexity to the learning experience but at the same time generates a model that is directly applicable to other courses and informal learning situations. Nevertheless, to assure the feasibility of the experience, the course previous to the one we analyse was also based in a similar approach. The results and the experience of the students were successful, validating the continuity and the interest in analysing the experience, as we are doing in this study.

\subsection{Measures}

All measures were obtained by adapting scales previously used in relevant studies to the educational context (all scales and items are shown in the annex):

The Attitude Toward Using (ATU) scale used in this paper is an adaptation of the 3item scale proposed by Chen, Gillenson, and Sherrell (2002).

To measure Student Loyalty (LOY), the classic 4-item scale developed by Zeithaml, Berry, and Parasuraman (1996) was used. The scale has two components: the behavioral intention to use social media-based learning (BIU) and the willingness to recommend it (WIR). Similar scales have been used in other studies (Helgesen, \& Nesset, 2007b; Li, \& Hung, 2009; Thomas, 2011). 
Arquero, J. L., del Barrio-García, S., \& Romero-Frías, E. (2016). What Drives Students' Loyalty-Formation in Social Media Learning Within a Personal Learning Environment Approach? The Moderating Role of Need for Cognition. Journal of Educational Computing Research, Volume: 55 issue: 4, page(s): 495-525

https://doi.org/10.1177/0735633116672056 Preprint for research purposes.

Please refer to the journal's page for the final version of the paper

Learning Satisfaction (SAT) was measured using the 2-item scale proposed by

Szymanski, and Hise (2000), later used in Szymanski, and Henard (2001), Evanschitzky et al. (2004) and Jayawardhena (2004).

With regard to the Need for Cognition (NFC), the original scales proposed by Cacioppo, and Petty (1982) and Cacioppo, Petty, and Kao (1984) were too large (34 and 18 items, respectively) to be used in a multi-scale design. Therefore, we opted to use a shortened version of the original NFC scale in the light of various studies (Gangadharbatla, 2008; Hughes et al., 2012; Del Barrio-García, Arquero, \& Romero-Frías, 2015). Specifically, we used the 5-item version proposed by Del Barrio-García, Arquero, and Romero-Frías (2015) in an education context.

Respondents were asked to answer to the questionnaire items on a 7-point Likert scale, ranging from (1) 'strongly disagree' to (7) 'strongly agree', except learning satisfaction where a 7 point semantic differential scale was used.

\subsection{Statistical procedure}

Techniques or statistical procedures for estimating a causal model differ depending on the aims of the analysis, the statistical suppositions on which they are based and the nature of the fit statistics they provide (Barroso, Cepeda, \& Roldán, 2010). On the one hand we find the covariance-based SEM (Lisrel, Amos, Mplus), which seeks to estimate the parameters of the model, minimizing the discrepancies between the initial covariance matrix of the data and the covariance matrix estimated by the proposed models (Bagozzi, 1980; Jöreskog, 1973). On the other hand, partial least squares path modeling (PLS-PM) provides an alternative to covariance-based SEM (Chin, 1998; Lohmöller, 1989; Wold, 1982). The aim of PLS-PM is to predict dependent variables, maximizing their explained variance. The advantages of PLS over covariance-based SEM include the minimum assumptions made for measurement scales, specification of measurement models (reflective or formative indicators), sample size and data distribution (Chin, Marcolin, \& Newsted, 1996). The theoretical model proposed in this study is therefore much better suited to the conditions for application of the PLS-PM technique, especially since our sample is relatively small (Chin, \& Newsted, 1999; 
Arquero, J. L., del Barrio-García, S., \& Romero-Frías, E. (2016). What Drives Students' Loyalty-Formation in Social Media Learning Within a Personal Learning Environment Approach? The Moderating Role of Need for Cognition. Journal of Educational Computing Research, Volume: 55 issue: 4, page(s): 495-525

https://doi.org/10.1177/0735633116672056 Preprint for research purposes.

Please refer to the journal's page for the final version of the paper

Rigdon, 2013). Also our model is not complex as it uses scales with few items, and PLS-PM can assure robustness of results (Qureshi, \& Compeau, 2009).

SmartPLS 3.2.4, developed by Ringle, Wende, and Becker (2015), was used to estimate the model to perform the PLS multi-group analysis (PLS-MGA) (High NFC vs Low NFC) and to assess the measurement invariance through the measurement invariance assessment procedure (MICOM).

The PLS multi-group analysis allows testing if pre-defined data groups have significant differences in their group-specific parameter estimates, providing outcomes of different approaches that are based on bootstrapping results from every group. Sarstedt, Henseler, \& Ringle (2011) describe the multi-group analysis methods in detail. Likewise, measurement invariance is an important issue when conducting PLS multi-group analyses. Group comparisons can be misleading unless researchers establish the invariance of their measures. Henseler, Ringle, \& Sarstedt (2016) introduce a procedure to assess measurement invariance of composite models (MICOM) before undertaking multi-group analyses in PLS-SEM. In addition, a bootstrapping procedure was used in all cases.

Furthermore, the K-means cluster analysis procedure was used to classify the respondents by NFC score. Two significantly different groups emerged: HIGH-NFC, 124 students with an NFC score of between 4.30 and 3.90; and LOW-NFC, 78 students with an NFC score of between 3.22 and 2.33. Our NFC scale showed adequate internal reliability (Cronbach's alpha: .727).

\section{Results}

The evaluation of the structural model has, in turn, three phases. The first one analyses the psychometric properties of the scales used and the discriminant validity of the constructs. The second compares the strength of the hypotheses by analyzing the estimated coefficients between the latent variables (paths). Finally, the third evaluates the model fit assessment and their predictive capacity. 
Arquero, J. L., del Barrio-García, S., \& Romero-Frías, E. (2016). What Drives Students' Loyalty-Formation in Social Media Learning Within a Personal Learning Environment Approach? The Moderating Role of Need for Cognition. Journal of Educational Computing Research, Volume: 55 issue: 4, page(s): 495-525

https://doi.org/10.1177/0735633116672056 Preprint for research purposes.

Please refer to the journal's page for the final version of the paper

Table 1 shows the adequate psychometric properties of the scales used to measure attitudes toward using, learning satisfaction and loyalty (willingness to recommend and behavioral intention to use) in both groups. All the loadings were significant, and the composite reliability (CR) and average variance extracted (AVE) values were above the recommended limits (.8 and .5) (Del Barrio, \& Luque, 2013; Hair, Hult, Ringle, \& Sarstedt, 2017). The discriminant validity of the constructs in each group was tested following the procedure proposed by Fornell, and Larcker (1981), in which the square root of the AVEs must be greater than the correlations between constructs. In addition, the Heterotrait-Monotrait (HTMT) ratio (Henseler, Ringle \& Sarstedt 2015) was computed for each pair of constructs on the basis of the item correlations. The computation yielded values below 1 or the most conservative criterion 0.90 (Gold, Malhotra \& Segars, 2001), thus providing evidence of discriminant validity (see Table 2).

-Insert Table 1 here-

-Insert Table 2 here-

Hult et al. (2008) noted that failure to establish measurement equivalence is a potential source of measurement error, which reduces the power of statistical tests of hypotheses and provides misleading results. Therefore, before testing the hypotheses, the measurement equivalence between groups was assessed applying the measurement invariance assessment procedure (MICOM) (Henseler, Ringle, \& Sarstedt, 2016). All the latent variables show compositional invariance, as long as there are no significant differences in the indicator weights for measurement paths between groups (HIGH_NFC vs. LOW_NFC) (p>.05) (see Table 3).

-Insert Table 3 here-

Once the properties of the scales had been examined the hypotheses were tested. Figure 2 shows the results of the structural (inner) model for the two groups of students, including the estimated coefficients and p-values resulting from the application of the bootstrap resampling procedure to 5,000 sub-samples (Hair et al., 2017). 
Arquero, J. L., del Barrio-García, S., \& Romero-Frías, E. (2016). What Drives Students' Loyalty-Formation in Social Media Learning Within a Personal Learning Environment Approach? The Moderating Role of Need for Cognition. Journal of Educational Computing Research, Volume: 55 issue: 4, page(s): 495-525

https://doi.org/10.1177/0735633116672056 Preprint for research purposes.

Please refer to the journal's page for the final version of the paper

H1 proposes that students' attitude toward social media usage is positively related to their loyalty toward social media. This hypothesis was confirmed only for the Low_NFC students, with a positive and significant coefficient $\left(\beta_{\mathrm{ATU}} \rightarrow \mathrm{LOY}_{-} \mathrm{LOW}_{-} \mathrm{NFC}: .37\right.$, $\mathrm{p}<.01)$. However, for High_NFC students attitude toward the using does not seem to determine loyalty as the coefficient was found to be positive but non-significant $\left(\beta_{\text {ATU } \rightarrow \text { LOY_HIGH_NFC: }} .06, p>.01\right)$. Meanwhile, $\mathrm{H} 2$ proposes that student satisfaction with social media is positively related to student loyalty toward social media. In this case this hypothesis is supported in both NFC groups as the coefficients were significant, high and positive $\left(\beta_{\mathrm{SAT}_{\rightarrow} \mathrm{LOY}_{-} \mathrm{HIGH} \_\mathrm{NFC}}: .70, \mathrm{p}<.01 ; \beta_{\mathrm{SAT}_{\rightarrow} \mathrm{LOY}_{-} \mathrm{LOW}_{-} \mathrm{NFC}}: .39, \mathrm{p}<.01\right)$, although much more strongly for High-NFC students.

H3 proposes that student attitude toward social media is positively related to student satisfaction with social media. Once again the hypothesis is supported in the two NFC groups with coefficients high, positive and significant $\left(\beta_{\text {ATU }_{\rightarrow} \text { SAT_HIGH_NFC: }} .57, \mathrm{p}<.01\right.$; $\left.\beta_{\mathrm{ATU}_{\rightarrow} \mathrm{SAT}_{-} \text {LOW_NFC: }} .79, \mathrm{p}<.01\right)$. Unlike $\mathrm{H} 2$ the relationship between attitude toward the using and satisfaction was stronger for Low_NFC students.

To examine H4, which states that NFC is a relevant moderator in the formation of students' loyalty toward social media learning, we tested whether the observed differences in the coefficients between the High_NFC and Low_NFC groups were significant. The multi-group invariance analysis (PLS-MGA) (Sarstedt, Henseler, \& Ringle, 2011) shows the existence of significant differences for the suggested relations between ATU, SAT and LOY (see Table 4 and Figure 2). Particularly, the effect of ATU on SAT is significantly greater for Low_NFC students than for High_NFC students (Diff. ATU $\rightarrow$ SAT (High vs Low): .214, p<.01). Nevertheless, the effect of SAT on LOY is greater for High_NFC students than for Low_NFC students (Diff. SAT $\rightarrow$ LOY (High vs Low): .308, $\mathrm{p}<.05)$. The effect of ATU on LOY is significantly greater $(\mathrm{p}<.05)$ for Low_NFC students; but it is not significant for High_NFC students (Diff. ATU $\rightarrow$ LOY (High vs Low): .310, $\mathrm{p}<.05)$. No differences between groups were found for the two dimensions

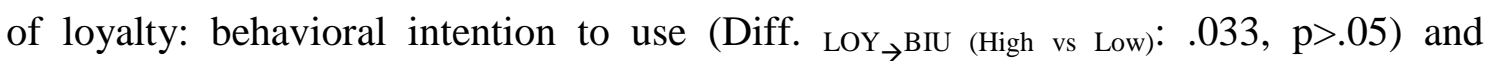


Arquero, J. L., del Barrio-García, S., \& Romero-Frías, E. (2016). What Drives Students' Loyalty-Formation in Social Media Learning Within a Personal Learning Environment Approach? The Moderating Role of Need for Cognition. Journal of Educational Computing Research, Volume: 55 issue: 4, page(s): 495-525

https://doi.org/10.1177/0735633116672056 Preprint for research purposes.

Please refer to the journal's page for the final version of the paper

willingness to recommend (Diff. LOY $\rightarrow$ WIR (High vs Low): .004, p>.05). These results support $\mathrm{H} 4$, indicating that the perception of social media learning and the way that loyalty toward the system is formed depend on the level of NFC.

-Figure 2 here-

-Insert Table 4 here-

These findings indicate that the loyalty of High_NFC students toward social media learning depends on the satisfaction they have derived from using these services. By contrast, for Low_NFC students, loyalty depends mainly on previous attitudes (and, to a lesser extent, on the satisfaction they have derived from social media learning). The total effects between the constructs (Table 5) reflect this difference. The relevance, in terms of total effects, of attitude toward the use of social media on satisfaction and loyalty (and its components) is greater for Low_NFC students.

Working to develop the student's satisfaction with the educational experience is much more important among High_NFC learners to foster loyalty toward social media learning. To conclude, we observed a moderated mediation effect in which student satisfaction acts as a mediator between attitudes and intentions, and where NFC moderates the level of this mediation. Learning satisfaction exerts full mediation in the relationship between attitudes toward using and student loyalty for Low_NFC students, whereas it exerts only partial mediation for High_NFC students.

-Insert Table 5 here-

Finally, table 6 presents the descriptive statistics for the main variables in the model by NFC group and the significance of the differences (ANOVA). It is to be noted that all the differences are statistically significant, supporting H5. High_NFC students present higher levels of attitude towards using, learning satisfaction, behavioral intention to use and willingness to recommend - suggesting better acceptance of this kind of innovation.

-Insert Table 6 here- 
Arquero, J. L., del Barrio-García, S., \& Romero-Frías, E. (2016). What Drives Students' Loyalty-Formation in Social Media Learning Within a Personal Learning Environment Approach? The Moderating Role of Need for Cognition. Journal of Educational Computing Research, Volume: 55 issue: 4, page(s): 495-525

https://doi.org/10.1177/0735633116672056 Preprint for research purposes.

Please refer to the journal's page for the final version of the paper

Having tested the hypotheses, the next and final stage consisted of evaluating the model fit and its predictive capacity.

It is to be noted that the assessment of the goodness of fit is not an objective of PLS-PM and that these measures must be used with caution (Hair et al., 2017). However, Henseler et al. (2014) introduced the standardized root mean square residual (SRMR) as a goodness of fit measure for PLS-PM, to date one of the most accepted model fit assessment criteria. The SRMR is defined as the difference between the observed correlation and the model implied correlation matrix. Thus, it allows assessing the average magnitude of the discrepancies between observed and expected correlations as an absolute measure of (model) fit criterion and can be used to avoid model misspecification. A value less than .10 (.08 in a more conservative approach; see $\mathrm{Hu} \&$ Bentler, 1999) are considered a good fit. The results obtained in both groups lead to the

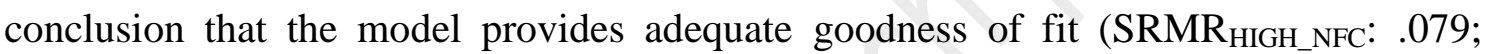
SRMR LOW_NFC: $_{\text {.087). }}$.

The evaluation of the predictive capacity of the model involves the examination of the percentage of explained variance of the dependent constructs $\left(\mathrm{R}^{2}\right)$, as well as their predictive relevance using the Stone-Geisser $Q^{2}$ value (Stone, 1974; Geisser, 1974). It is established that if $\mathrm{Q}^{2}>0$, the model has predictive relevance. By analyzing the results obtained for the four dependent variables of our model (see Figure 2), we can conclude that all of them present suitable percentages of explained variance and predictive relevance in both groups (Hair et al., 2017).

\section{Discussion and conclusion}

During the last two decades, different labels have been used to define new generations of students who have grown up with digital technologies: 'digital natives' (Prensky, 2001), 'Net generation' (Tapscott, 1998) and 'millenials' (Howe, \& Strauss, 2000, 2003), among others. One negative effect of these conceptualizations based on a disruptive view of the technological change in education is the assumption that there is one single set of learning preferences and styles associated with a whole generation (Bennet, Maton, \& Kervin, 2008). Given that digital technology usage for social 
Arquero, J. L., del Barrio-García, S., \& Romero-Frías, E. (2016). What Drives Students' Loyalty-Formation in Social Media Learning Within a Personal Learning Environment Approach? The Moderating Role of Need for Cognition. Journal of Educational Computing Research, Volume: 55 issue: 4, page(s): 495-525

https://doi.org/10.1177/0735633116672056 Preprint for research purposes.

Please refer to the journal's page for the final version of the paper

purposes among young people is very high (Perrin, 2015), educators might usefully take advantage of these resources and incorporate social media into their courses, for educational purposes. However, in order to design effective e-learning environments it is vital for instructors to understand the target group's needs and motivations and to adopt strategies that facilitate learners' adoption of the technology for educational ends and future professional use (Liaw et al., 2007). On this premise, the main aim of the present study is to understand how loyalty to such systems is formed and how learners' personal levels of NFC moderate this loyalty-formation through a model that combines simplicity, clarity and, particularly, predictive relevance. While the use of social media is not a goal in itself, it does constitute an ambitious strategy for preparing students for lifelong learning through the PLE approach. PLEs provide, as previously indicated, an innovative perspective that helps students become more self-aware in their learning processes and preferences, through the integration of services that are generally used by them for social purposes.

Our results highlight that certain characteristics of students - NFC in this case -can have a significant influence on the success of educational experiences using social media and how the experiences are perceived. High-NFC students present higher levels of positive attitude toward the use of social media, behavioral intention to use them and also willingness to recommend their use to their colleagues, in comparison to low-NFC students. High-NFC students also perceive the experience as more satisfactory (that is, they present higher levels of learning satisfaction).

The level of NFC not only exerts an influence on the main variables in the model, as noted, but also affects how these variables interact, significantly moderating the formation of loyalty toward social medial learning. For high-NFC students, the learning satisfaction with the experience is the most important variable to explain loyalty; whereas for low-NFC students the importance of learning satisfaction is much lower, and attitudes have a stronger effect on loyalty.

These results have educational implications. In order to improve the acceptance of social media learning, different strategies could be implemented depending on the NFC 
Arquero, J. L., del Barrio-García, S., \& Romero-Frías, E. (2016). What Drives Students' Loyalty-Formation in Social Media Learning Within a Personal Learning Environment Approach? The Moderating Role of Need for Cognition. Journal of Educational Computing Research, Volume: 55 issue: 4, page(s): 495-525

https://doi.org/10.1177/0735633116672056 Preprint for research purposes.

Please refer to the journal's page for the final version of the paper

level of students. As stated earlier, educational experiences based on the use of PLEs give students flexibility to set and pursue their own learning objectives. In formal education settings this approach is flexible enough for instructors to design the optimal conditions for improving the loyalty level of the students.

On the one hand, high-NFC individuals can benefit from a learning approach that can be adapted to their own interests and therefore increase their overall positive assessment of their learning experience (Keller, 1983). On the other hand, low-NFC individuals have a preference for particular characteristics related to their attitude towards using technologies (if the use of the tools is comfortable, safe or if it saves time, for instance). Teachers should be able to provide students with different educational experiences in the use of technology in order to improve its acceptance.

Previous literature provides some useful insights into possible alternatives. Cacioppo et al. (1996) suggest that high-NFC individuals, in comparison to low-NFC individuals, prefer engaging in complex situations and are more confident and persuasive in championing their ideas. They also have a preference for situations that offer novelty, complexity and uncertainty. Curiosity to seek new information and opportunities and to create new knowledge (Evans, Kirby, \& Fabrigar, 2003) is another characteristic of high-NFC individuals. Activities designed to expose students to vast amounts of information in social media that is accessible to be discovered, filtered and used in creative ways can increase their satisfaction.

Along similar lines, Dollinger (2003) stated that NFC is positively related to selfreported creative behaviors. According to Nair, and Ramnarayan (2000), high-NFC people can quickly process information that is helpful in generating new ideas and solving complex problems. Methodologies using social media that require creative and proactive solutions, such as project-based learning, could well suit high-NFC students.

Low-NFC students, by contrast, are more dependent on others, provide less information to solve problems (particularly when it is contradicting) and show less engagement in cognitive tasks (Kaynar, \& Amichai-Hamburger, 2008). For them, an overall positive 
Arquero, J. L., del Barrio-García, S., \& Romero-Frías, E. (2016). What Drives Students' Loyalty-Formation in Social Media Learning Within a Personal Learning Environment Approach? The Moderating Role of Need for Cognition. Journal of Educational Computing Research, Volume: 55 issue: 4, page(s): 495-525

https://doi.org/10.1177/0735633116672056 Preprint for research purposes.

Please refer to the journal's page for the final version of the paper

assessment of the learning experience is not as relevant as for high-NFC individuals. For low-NFC students, interventions that positively shape their attitudes toward the technology used and the prospects for their future in terms of employability and lifelong learning can be more useful. On this note, Thompson, Chaiken, and Hazlewood (1993) highlighted that NFC involves intrinsic motivation for effortful cognitive processing; therefore low-NFC students could be more strongly driven by external motives. A stronger link between performance in activities and external rewards in terms of grades could be a useful measure to motivate low-NFC students.

In short, different strategies followed by the instructor may lead to an increase in loyalty toward social media learning, improving the development of students' PLEs. If teachers were able to determine the NFC profiles of their students prior to undertaking a course or learning experience they could use this data to create homogeneous groups within the overall class and provide personalized learning according to NFC level. Hence, the students would benefit from tailored input about social media learning and the importance of developing their PLE for their professional careers, focusing either on their attitudes toward the technology or on the level of satisfaction with the experience.

\section{Limitations and further research}

The study has two main limitations. First, it was conducted in one country only (Spain), among students from one particular area of knowledge. Students' profile from other areas of knowledge could generate different results. Therefore, it is necessary to extend this type of experience and research to other cases. Second, the size of the sample is relatively low, albeit big enough to generalize the results.

Further research should take into account the factors influencing teaching strategies used in the classroom (Anderson, Groulx, \& Maninger, 2011; Li, Li, \& Franklin, 2016), as long as it might be determinant to understand the final adoption by students. Also we recognise the practical interest in elaborating a more qualitative and applied resource that could provide teachers with strategies and tools that could be adapted to their specific circumstances. Further research should also explore other measures of users' approach to learning - for example, as an alternative to NFC, students' learning styles could be assessed (Biggs, 
Arquero, J. L., del Barrio-García, S., \& Romero-Frías, E. (2016). What Drives Students' Loyalty-Formation in Social Media Learning Within a Personal Learning Environment Approach? The Moderating Role of Need for Cognition. Journal of Educational Computing Research, Volume: 55 issue: 4, page(s): 495-525

https://doi.org/10.1177/0735633116672056 Preprint for research purposes.

Please refer to the journal's page for the final version of the paper

1987). Also, the key role of learning satisfaction for high-NFC students implies that, in this case, the characteristics of the PLE that are linked to greater learning satisfaction need to be studied in some depth. For all the students (high- and low-NFC), the characteristics of the PLE that impact on attitudes toward social media in education should also be examined. Finally, research on the maintenance of these learning practices along the students' professional lives are needed in order to assess the impact in lifelong learning.

Nevertheless, although significantly different, the scores for both high- and low-NFC students were relatively high. These positive values in both groups might be due to the fact that the study was carried out in an elective subject in the final year of the degree. Further research may be needed to test these differences earlier in the degree program and with a greater diversity of students.

\section{Declaration of Conflicting Interests}

The authors declared no potential conflicts of interest with respect to the research, authorship, and/or publication of this article.

\section{Funding}

This work was supported by the Andalusian Program for R\&D [grant number P12SEJ2592].

\section{References}

Hair, J.F., Hult, G., Tomas, M., Ringle, C.M., \& Sarstedt, M. (2014). A primer on partial least squares structural equation modeling (PLS-SEM). Thousand Oaks, CA: Sage Publications.

AIMC - Association for the research in communication media. (2014). 15 encuesta AIMC a usuarios de Internet. Retrieved from http://www.aimc.es/-Navegantesen-la-Red-.html

Ajjan, H., \& Hartshorne, R. (2008). Investigating faculty decisions to adopt Web 2.0 technologies: theory and empirical tests. The Internet and Higher Education, 11(2), 71-80.

Ajzen, I. (1991). The theory of planned behavior. Organizational Behavior and Human Decision Processes, 50, 179-211. 
Ali, F., Zhou, Y., Hussain, K., Nair, P.K., \& Ragavan, N.A. (2016). Does higher education service quality effect student satisfaction, image and loyalty? A study of international students in Malaysian public universities. Quality Assurance in Education, 24(1), 70-94.

Allen, J., \& van der Velden, R., eds. (2011). The flexible professional in the knowledge society. New challenges for higher education. Springer.

Anderson, S.E., Groulx, J.G., \& Maninger, R.M. (2011). Relationships among preservice teachers' technology-related abilities, beliefs, and intentions to use technology in their future classrooms. Journal of Educational Computing Research, 45(3), 321-338.

Andreassen, T.W., \& Lindestad, B. (1998). Customer loyalty and complex services: The impact of corporate image on quality, customer satisfaction and loyalty for customers with varying degrees of service expertise. International Journal of Service Industry Management, 9(1), 7-23.

Annamdevula , S., Bellamkonda, R.S. (2016). The effects of service quality on student loyalty: the mediating role of student satisfaction. Journal of Modelling in Management, 11(2), 446-462.

Arquero, J.L., \& Romero-Frías, E. (2013). Using social network sites in higher education: an experience in business studies. Innovations in Education and Teaching International, 50(3), 238-249.

Arteaga Sánchez, R., \& Duarte Hueros, A. (2010). Motivational factors that influence the acceptance of Moodle using TAM. Computers in Human Behavior, 26(6), $1632-1640$.

Athiyaman, A. (1997). Linking student satisfaction and service quality perceptions: the case of the university education. European Journal of Marketing, 31(7), 528-540.

Attwell, G. (2007). The personal learning environments - the future of elearning? eLearning Papers, 2(1). Retrieved from http://www.openeducationeuropa.eu/en/article/Personal-Learning-Environments--the-future-of-eLearning\%3F?paper $=57211$

Bagozzi, R.P. (1980). Causal models in marketing. New York: John Wiley.

Bailey, J.E., \& Pearson, S.W. (1983). Development of a tool for measuring and analyzing computer user satisfaction. Management Science, 29(5), 530-545.

Barroso, C., Cepeda, G., \& Roldán, J.L. (2010). Applying maximum likelihood and PLS on different sample sizes: Studies on SERVQUAL model and employee behavior model. In V. Vinzi, W.W. Chin, J. Henseler, and H. Wang (Eds.), Handbook of partial least squares, (pp. 427-447). Berlin: Springer-Verlag.

Bhattacherjee, A. (2001a). Understanding information systems continuance: an expectation-confirmation mode. MIS Quarterly, 25 (3), 351-370.

Bhattacherjee, A. (2001b). An empirical analysis of the antecedents of electronic commerce service continuance. Decision Support Systems, 32(2), 201-214.

Biggs, J.B. (1987). Student approaches to learning and studying. Hawthorn,Vic.: Australian Council for Educational Research.

Bok, D. (2013). Higher Education in America. Princeton University Press.

Bowen, J.T., \& Chen, S.L. (2001). The relationship between customer loyalty and customer satisfaction. International journal of contemporary hospitality management, 13(5), 213-217.

Bull, G., Thompson, A., Searson, M., Garofalo, J., Park, J., Young, C., \& Lee, J. (2008). Connecting informal and formal learning experiences in the age of 
Arquero, J. L., del Barrio-García, S., \& Romero-Frías, E. (2016). What Drives Students' Loyalty-Formation in Social Media Learning Within a Personal Learning Environment Approach? The Moderating Role of Need for Cognition.

participatory media. Contemporary Issues in Technology and Teacher Education, 8(2), 100-107.

Cacioppo, J.T., \& Petty, R.E. (1982). The need for cognition. Journal of Personality and Social Psychology, 42(1), 116-131.

Cacioppo, J.T., Petty, R.E., \& Kao, C.F. (1984). The efficient assessment of need for cognition. Journal of Personality Assessment, 48(3), 306-307.

Cacioppo, J.T., Petty, R.E., Feinstein, J.A., \& Jarvis, W.B.G. (1996). Dispositional differences in cognitive motivation: The live and times of individuals varying in need for cognition. Psychological Bulletin, 119(2), 197-253.

Casaló, L.V., Flavián, C., \& Guinalíu, M. (2008a). The role of satisfaction and website usability in developing customer loyalty and positive word-to-mouth in the ebanking services. The International Journal of Bank Marketing, 26(6), 399-417.

Casaló, L.V., Flavián, C., \& Guinalíu, M. (2008b). The role of perceived usability, reputation satisfaction and consumer familiarity on the website loyalty formation process. Computers in Human Behavior, 24(2), 325-345.

Castañeda, J.A., Rodríguez, M.A., \& Luque, T. (2009). Attitudes' hierarchy of effects in online user behavior. Online Information Review, 33(1), 7-21.

Castañeda, L., \& Adell, J. (2013). Entornos personales de aprendizaje: claves para el ecosistema educativo en red. Alcoi: Marfil.

Chatti, A., Jarke, M., \& Specht, M. (2011). The 3P learning model. Educational Technology \& Society, 13(4), 74-85.

Chen, C.-H., \& Wu, I.-C. (2012). The interplay between cognitive and motivational variables in a supportive online learning system for secondary physical education. Computers \& Education, 58(1), 542-550.

Chen, L., Gillenson, M.L., \& Sherrell, D.L. (2002). Enticing online consumer: an expected technology acceptance perspective. Information \& Management, 39(8), 705-719.

Chin, W.W. (1998). The partial least squares approach to structural equation modelling. In G.A. Marcoulides (Ed.), Modern methods for business research (pp. 295-336). Mahwah, NJ: Lawrence Erlbaum Associates, Publisher.

Chin, W.W., \& Newsted, P.R. (1999). Structural equation modeling analysis with small samples using partial least squares. In R.H. Hoyle (Ed.), Statistical Strategies for Small Sample Research (pp. 307-341). Thousand Oaks: Sage.

Chin, W.W., Marcolin, B.L., \& Newsted, P.R. (1996). A partial least squares latent variable modeling approach for measuring interaction effects: Results from a Monte Carlo simulation study and voice mail emotion/adoption study. Proceedings of the 17th International Conference on Information Systems. Cleveland, Ohio.

Close, A. G., Lacey, R., \& Cornwell, T. B. (2015). Visual Processing and Need for Cognition Can Enhance Event-Sponsorship Outcomes. Journal of Advertising Research, 55(2), 206-215.

Cohen, A., Scotland, E., \& Wolfe, D. (1955). An experimental investigation of need for cognition. Journal of Abnormal and Social Psychology, 51(2), 291-294.

Cronin, J.J., \& Taylor S. (1992). Measuring service quality: A re-examination and extension. Journal of Marketing, 56(1), 55-68.

Dabbagh, N., \& Kitsantas, A. (2012). Personal learning environments, social media, and self-regulated learning: A natural formula for connecting formal and informal learning. The Internet and higher education, 15(1), 3-8. 
Dabbagh, N., \& Reo, R. (2011). Impact of Web 2.0 on higher education. In D.W. Surry, T. Stefurak, and R. Gray (Eds.), Technology integration in higher education: Social and organizational aspects (pp. 174-187). Hershey, PA: IGI Global.

Das, S., Echambadi, R., McCardle, M., \& Luckett, M. (2003). The effect of interpersonal trust, need for cognition, and social loneliness on shopping, information seeking, and surfing on the web. Marketing Letters, 14(3), 185-202.

Davis, F.D., Bagozzi, R.P., \& Warshaw, P.R. (1989). User acceptance of user technology: A comparison of two theoretical models. Management Science, 35(8), 982-1002.

Del Barrio, S., \& Luque, T. (2013). Análisis de ecuaciones estructurales. In T. Luque (Ed.), Técnicas de Análisis de datos en investigación de mercados (pp. 525-610). Barcelona: Pirámide.

Del Barrio-García, S., Arquero, J.L., \& Romero-Frías, E. (2015). Personal learning environments acceptance model: The role of need for cognition, e-Learning satisfaction and students' perceptions. Educational Technology \& Society, 18(3), 129-141.

DeShon, R.P., \& Gillespie, J.Z. (2005). A motivated action theory account of goal orientation. Journal of Applied Psychology, 90(6), 1096.

Dick, A.S., \& Basu, K. (1994). Customer loyalty: toward an integrated conceptual framework. Journal of the Academy of Marketing Science, 22(2), 99-113

EDUCAUSE Learning Initiative (ELI). (2009). The seven things you should know about... Personal Learning Environments. Retrieved from http://net.educause.edu/ir/ library/pdf/ELI7049.pdf

Ekinci, Y., \& Riley, M. (2003). An investigation of self-concept: actual and ideal selfcongruence compared in the context of service evaluation. Journal of Retailing and Consumer Services, 10(4), 201-214.

Elliott, K.M., \& Healy, M.A. (2001). Key factors influencing student satisfaction related to recruitment and retention. Journal of marketing for higher education, 10(4), 1-11.

European Commission 2012.Rethinking Education: Investing in skills for better socioeconomic outcomes. Retrieved from http://ec.europa.eu/newsroom/dae/document.cfm?doc_id=2877

Evans, C.J., Kirby, J.R., \& Fabrigar, L.R. (2003). Approaches to learning, need for cognition, and strategic flexibility among university students. British Journal of Educational Psychology, 73(4), 507-528.

Evanschitzky, H., \& Wunderlich, M. (2006). An examination of moderator effects: The four stage loyalty model. Journal of Service Research, 8(4), 330-345.

Evanschitzky, H., Gopalkrishnan, R.I., Hessea, J., \& Ahlerta, D. (2004). E-satisfaction: a re-examination. Journal of Retailing, 80(3), 239-247.

Fishbein, M., \& Ajzen, I. (1975). Belief, attitude, intention and behavior: an introduction to theory and research. Reading, Massachusetts: Addison-Wesley.

Fornell, C., \& Larcker, D.F. (1981). Evaluating structural equation models with unobservable variables and measurement error. Journal of Marketing Research, 18(1), 39-50.

Gangadharbatla, H. (2008). Facebook me: Collective self-esteem, need to belong, and internet self-efficacy as predictors of the generation's attitudes toward social networking sites. Journal of Interactive Advertising, 8(2), 5-15. 
Arquero, J. L., del Barrio-García, S., \& Romero-Frías, E. (2016). What Drives Students' Loyalty-Formation in Social Media Learning Within a Personal Learning Environment Approach? The Moderating Role of Need for Cognition. Journal of Educational Computing Research, Volume: 55 issue: 4, page(s): 495-525

https://doi.org/10.1177/0735633116672056 Preprint for research purposes.

Please refer to the journal's page for the final version of the paper

Giese, J.L., \& Cote, J.A. (2000). Defining customer satisfaction. Academy of Marketing Science Review, 1, 1-34.

Gold, A.H., Malhotra, A., \& Segars, A.H. (2001). Knowledge Management: An Organizational Capabilities Perspective. Journal of Management Information Systems, 18(1), 185-214.

Gotlieb, J.B., Grewal, D., \& Brown, S.W. (1994). Consumer satisfaction and perceived quality: complementary or divergent constructs? Journal of Applied Psychology, 79(6), 875-888.

Gupta, K., \& Stewart, D.W. (1996). Customer satisfaction and customer behavior: the differential role of brand and category expectations. Marketing Letters, 7(3), 249263.

Hair, J. F., Hult, G. T. M., Ringle, C. M., \& Sarstedt, M. (2017). A Primer on Partial Least Squares Structural Equation Modeling. 2nd Edition. Thousand Oaks: Sage.

Häkkinen, P., \& Hämäläinen, R. (2011). Shared and personal learning spaces: Challenges for pedagogical design. The Internet and Higher Education, 14(4), 231-236.

Han, H., and Ryu, K. (2009). The roles of the physical environment, price perception, and customer satisfaction in determining customer loyalty in the family restaurant industry. Journal of Hospitality and Tourism Research, 33(4), 487-510.

Hayashi, A., Chen, C., Ryan, T., \& Wu, J. (2004). The role of social presence and moderating role of computer self-efficacy in predicting the continuance usage of e-learning systems. Journal of Information Systems Education, 15(2), 139-154.

Helgesen, Ø., \& Nesset, E. (2007a). Images, satisfaction and antecedents: Drivers of student loyalty? A case study of a Norwegian university college. Corporate Reputation Review, 10(1), 38-59.

Helgesen, Ø., \& Nesset, E. (2007b). What accounts for students' loyalty? Some field study evidence. International Journal of Educational Management, 21(2), 126143.

Hennig-Thurau, T., Langer, M. F., \& Hansen, U. (2001). Modeling and managing student loyalty an approach based on the concept of relationship quality. Journal of sService rResearch, 3(4), 331-344.

Henseler, J., Dijkstra, T.K., Sarstedt, M., Ringle, C.M., Diamantopoulos, A., Straub, D.W., Ketchen, D.J., Hair, J.F., Hult, G.T. M., \& Calantone, R.J. (2014). Common Beliefs and Reality about Partial Least Squares: Comments on Rönkkö \& Evermann (2013), Organizational Research Methods, 17(2), 182-209.

Henseler, J., Ringle, C.M., \& Sarstedt, M. (2015). A New Criterion for Assessing Discriminant Validity in Variance-Based Structural Equation Modeling. Journal of the Academy of Marketing Science, 43(1), 115-135.

Henseler, J., Ringle, C.M., \& Sarstedt, M. (2016). Testing measurement invariance of composites using partial least squares. International Marketing Review,. 33(3), 405-431.

Hill, B. D., Foster, J. D., Elliott, E. M., Shelton, J. T., McCain, J., \& Gouvier, W. D. (2013). Need for cognition is related to higher general intelligence, fluid intelligence, and crystallized intelligence, but not working memory. Journal of Research in Personality, 47(1), 22-25.

Hildebrandt, C. (1998). Developing mathematical understanding through invented games. Teaching Children Mathematics. 5(3), 191-195. 
Arquero, J. L., del Barrio-García, S., \& Romero-Frías, E. (2016). What Drives Students' Loyalty-Formation in Social Media Learning Within a Personal Learning Environment Approach? The Moderating Role of Need for Cognition. Journal of Educational Computing Research, Volume: 55 issue: 4, page(s): 495-525

https://doi.org/10.1177/0735633116672056 Preprint for research purposes.

Please refer to the journal's page for the final version of the paper

Howe, N., \& Strauss,W. (2000). Millennials rising: the next great generation. New York: Vintage.

Howe, N., \& Strauss,W. (2003). Millennials go to college. Washington, DC: American Association of Collegiate Registrars and Admissions Officers.

Hu, L.-t., \& Bentler, P.M. (1998). Fit Indices in Covariance Structure Modeling: Sensitivity to Underparameterized Model Misspecification. Psychological Methods, 3(4), 424-453.

Hughes, D. J., Rowe, M., Batey, M., \& Lee, A. (2012). A tale of two sites: Twitter vs. Facebook and the personality predictors of social media usage. Computers in Human Behavior, 28(2), 561-569.

Hult, G.T.M., Ketchen, D.J., Griffith, D.A., Finnegan, C.A., Gonzalez-Padron, T., Harmancioglu, N.,...Cavusgil, S.T. (2008). Data equivalence in cross-cultural international business research: Assessment and guidelines. Journal of International Business Studies, 39(6), 1027-1044.

Hunt, H.K. (1977). CS/D: overview and future research directions. In H.K. Hunt (Ed.), Conceptualization and measurement of consumer satisfaction and dissatisfaction (pp. 455-488). Cambridge, MA: Marketing Science Institute.

Ives, B., Olson, M.H., \& Baroudi, J.J. (1983). The measurement of user information satisfaction. Communications of the ACM, 26(10), 785-793.

Jayawardhena, C. (2004). Personal values' influence on e-shopping attitude and behaviour. Internet Research, 14(2), 127-138.

Johnson, L., Adams Becker, S., Estrada, V., \& Freeman, A. (2015). NMC Horizon Report: 2015 Higher Education Edition. Austin, Texas: The New Media Consortium.

Jones, T.O., \& Sasser, W.E. (1995). Why satisfied customers defect. Harvard Business Review, 73(6), 88-102.

Jöreskog, K.G. (1973). Analysis of covariance structures. In P.R. Krishnaiah (Ed.), Multivariate analysis, vol. III (pp. 263-285). New York: Academic Press.

Kai-Wen, C. (2011). An empirical study on relationship of need for cognition, attitudes, and intention before installation of corporate e-learning programs in Taiwan. WSEAS Transactions on Information Science and Applications, 8(1), 285-292.

Kaynar, O., \& Amichai-Hamburger, Y. (2008). The effects of need for cognition on Internet use revisited. Computers in Human Behavior, 24(2), 361-371.

Keller, J. (1983). Motivational design of instruction. In C. Reigeluth (Ed.), Instructional design theories and models: An overview of their current status ( $\mathrm{pp}$. 386-434). Hillsdale, NJ: Erlbaum.

Kühl, T., Eitel, A., Damnik, G., \& Körndle, H. (2014). The impact of disfluency, pacing, and students' need for cognition on learning with multimedia. Computers in Human Behavior, 35, 189-198.

Ku, Y.C., Chen, R., \& Zhang, H. (2013). Why do users continue using social networking sites? An exploratory study of members in the United States and Taiwan. Information \& Management, 50(7), 571-581.

Lee, J.W. (2010). Online support service quality, online learning acceptance, and student satisfaction. The Internet and Higher Education, 13(4), 277-283.

Li, C.K., \& Hung, C.H. (2009). Marketing tactics and parents' loyalty: the mediating role of school image. Journal of Educational Administration, 47(4), 477-489. 
Li, K., Li, Y, \& Franklin, T. (2016). Preservice teachers' intention to adopt technology in their future classrooms. Journal of Educational Computing Research, In press, available online before print April 10, 2016, doi:10.1177/0735633116641694

Liaw, S.S., Huang, H.M., \& Chen, G.D. (2007). Surveying instructor and learner attitudes toward e-learning. Computers Education, 49(4), 1066-1080.

Lim, K.H., Benbasat, I., \& Ward, L.M. (2000). The role of multimedia in changing first impression bias. Information Systems Research, 11(2), 115-136.

Lin, C.S., Wu, S., \& Tsai, R.J. (2005). Integrating perceived playfulness into expectation-confirmation model for web portal context. Information \& Management, 42(5), 683-693.

Liu, I.F., Chen, M.C., Sun, Y.S., Wible, D., \& Kuo, C.H. (2010). Extending the TAM model to explore the factors that affect intention to use an online learning community. Computers \& Education, 54(2), 600-610.

Liu, S.H., Liao, H.L., \& Pratt, J.A. (2009). Impact of media richness and flow on elearning technology acceptance. Computers \& Education, 52(3), 599-607.

Lohmoller, J.B. (1989). Latent variable path modeling with partial least squares. Heidelberg, Germany: Physica-Verlag Heidelberg.

Mano, H., \& Oliver, R.L. (1993). Assessing the dimensionality and structure of the consumption experience: evaluation, feeling, and satisfaction. Journal of Consumer Research, 20(3), 451-466.

Marzo-Navarro, M., Pedraja-Iglesias, M., \& Rivera-Torres, P. (2005). Measuring customer satisfaction in summer courses. Quality Assurance in Education, 13 (1), 53-65.

Mason, R. (2006). Learning technologies for adult continuing education. Studies in Continuing Education, 28(2), 121-133.

Mazursky, D., \& Jacoby, J. (1986). Exploring the development of store images. Journal of Retailing, 62(2), 145-65.

McFarlin, D. B., and Sweeney, P. D. (1992), "Research Notes. Distributive and Procedural Justice as Predictors of Satisfaction with Personal and Organisational Outcomes", Academy of Management Journal, Vol. 35 No. 3, pp. 626-637.

McGloughlin, C., \& Lee, M.J.W. (2010). Personalised and self-regulated learning in the Web 2.0 era: International exemplars of innovative pedagogy using social software. Australasian Journal of Educational Technology, 26(1), 28-43.

Melone, N. (1990). A theoretical assessment of the user-satisfaction construct in information systems research. Management Science, 36(1), 76-91.

Meyers, E.M., Erickson, I., \& Small, R.V. (2013). Digital literacy and informal learning environments: an introduction. Learning, Media and Technology, 38(4), 355-367

Nair, K.U., \& Ramnarayan, S. (2000). Individual differences in need for cognition and complex problem solving. Journal of Research in Personality, 34(3), 305-328.

Ngai, E.W., Poon, J.K.L., \& Chan, Y.H.C. (2007). Empirical examination of the adoption of WebCT using TAM. Computers \& Education, 48(2), 250-267.

O'Reilly, T. (2005). What is Web 2.0. Retrieved from http://www.oreillynet.com/pub/a/oreilly/tim/news/2005/09/30/what-is-web20.html

Ozkan, S., \& Koseler, R. (2009). Multi-dimensional students' evaluation of e-learning systems in the higher education context: An empirical investigation. Computers \& Education, 53(4), 1285-1296. 
Park, J.H. (2014). The effects of personalization on user continuance in social networking sites. Information Processing \& Management, 50(3), 462-475.

Perrin, A. (2015). Social media usage: 2005-2015. Pew Research Center. Retrieved from http://www.pewinternet.org/2015/10/08/social-networking-usage-2005$2015 /$

Petrick, J.F. (2004). First timers' and repeaters' perceived value. Journal of Travel Research, 43(1), 29-38

Petty, R.E., \& Cacioppo, J.T. (1981). Attitudes and Persuasion: Classic and contemporary approaches. Dubuque, LA: A.C. Brown.

Podsakoff, M.P., MacKenzie, S. B., Lee, J. and Podsakoff, N. P. (2003), "Common Method Biases in Behavioral Research: A Critical Review of the Literature and Recommended Remedies", Journal of Applied Psychology, Vol. 8 No. 5, pp. 879-903.

Prenksy, M. (2001). Digital natives, digital immigrants. On the Horizon, 9(5), 1-6.

Qureshi, I., \& Compeau, D. (2009). Assessing between groups differences in IS research: A comparison of covariance and component-based SEM. MIS Quarterly, 33(1), 199-216.

Redecker, C., Ala-Mutka, K., Bacigalupo, M., Ferrari, A., \& Punie, Y. (2010). Learning 2.0: The impact of Web 2.0 innovations on education and training in Europe (Final Report). Institute for Prospective Technological Studies. European Commission. Retrieved from http://ftp.jrc.es/EURdoc/JRC55629.pdf

Richardson, W. (2009). Blogs, Wikis, podcasts, and other powerful tools for classrooms. Corwin Press.

Rigdon, E.E. (2013). Rethinking partial least squares path modeling: In praise of simple methods. Long Range Planning, 45(5/6), 341-358

Ringle, C.M., Wende, S., \& Becker, J-M. (2015). SmartPLS 3. Bönningstedt: SmartPLS. Retrieved from http://www.smartpls.com

Roca, J.C., Chiub, C.M., \& Martínez, F.J. (2006). Understanding e-learning continuance intention: An extension of the technology acceptance model. International Journal Human-Computer Studies, 64(8), 683-696.

Romero-Frías, E., \& Arquero, J.L. (2013). A view on personal learning environments through approaches to learning. Journal for Innovation and Quality in Learning (INNOQUAL), 1(1), 29-36.

Sanchez-Franco, M.J. (2010). WebCT-the quasimoderating effect of perceived affective quality on an extending technology acceptance model. Computers \& Education, 54(1), 37-46.

Sarstedt, M., Henseler, J., \& Ringle, C.M. (2011). Multigroup analysis in partial least squares (PLS) path modeling: Alternative methods and empirical results. Advances in International Marketing, 22(1), 195-218.

Schertzer, C.B., \& Schertzer, S.M.B. (2004). Student satisfaction and retention: a conceptual model. Journal of Marketing for Higher Education, 14(1), 79-91.

Selwyn, N. (2007). Web 2.0 applications as alternative environments for informal learning-A critical review. OECD CERIKERIS International expert meeting on ICT and educational performance. Cheju Island, South Korea: Organization for Economic Co-Operation and Development.

Shoemaker, S., \& Lewis, R.C. (1999). Customer loyalty: the future of hospitality marketing. International Journal of Hospitality Management, 18(4), 345-370 
Arquero, J. L., del Barrio-García, S., \& Romero-Frías, E. (2016). What Drives Students' Loyalty-Formation in Social Media Learning Within a Personal Learning Environment Approach? The Moderating Role of Need for Cognition. Journal of Educational Computing Research, Volume: 55 issue: 4, page(s): 495-525

https://doi.org/10.1177/0735633116672056 Preprint for research purposes.

Please refer to the journal's page for the final version of the paper

Shu-Sheng, L., \& Hsiu-Mei, H. (2011). Exploring learners' acceptance toward mobile learning. In T. Teo (Ed.), Technology Acceptance in Education (pp, 145-157). Rotterdam: Sense Publishers.

Sicilia, M., Ruiz, S., \& Munuera, J.L. (2005). Effects of interactivity in a Web site. Journal of Advertising, 34(3), 31-45.

Solomon, G., \& Schrum, L. (2007). Web 2.0: New tools, new schools. ISTE (International Society for Technology in Education).

Sultan, P., \& Yin Wong, H. (2014). An integrated-process model of service quality, institutional brand and behavioural intentions: The case of a University. Managing Service Quality, 24(5), 487-521.

Szymanski, D.M., \& Henard, D.H. (2001). Customer satisfaction: A meta-analysis of the empirical evidence. Journal of the Academy of Marketing Science, 21(1), 1625.

Szymanski, D.M., \& Hise, R.T. (2000). e-Satisfaction: An initial examination. Journal of Retailing, 76(3), 309-322.

Tam, J.L.M. (2000). The effects of service quality, perceived value and customer satisfaction on behavioural intentions. Journal of Hospitality and Leisure Marketing, 6(4), 31-43

Tapscott, D. (1998). Growing up digital: the rise of the Net generation. New York: McGraw-Hill.

Tess, P.A. (2013). The role of social media in higher education classes (real and virtual): A literature review. Computers in Human Behavior, 29(5), A60-A68

Thomas, S. (2011). What drives student loyalty in universities: an empirical model from India. International Business Research, 4(2), 183-192.

Thompson, E.P., Chaiken, S., \& Hazlewood, J.D. (1993). Need for cognition and desire for control as moderators of extrinsic reward effects: A person $\mathrm{x}$ situation approach to the study of intrinsic motivation. Journal of Personality and Social Psychology, 64(6), 987-999.

Tu, C-H., Sujo-Montes, L., Yen, C-J., Chan, J-Y., \& Blocher, M. (2012). The integration of personal learning environments \& open network learning environments. TechTrends, 56(3), 13-19.

Turner, J.S., \& Croucher, S.M. (2013). An examination of the relationships among United States college students' media use habits, need for cognition, and grade point average. Learning, Media and Technology, 39(2), 199-214.

Verplanken, B. (1993). Need for cognition and external information search: Responses to time pressure during decision-making. Journal of Research in Personality, $27(3), 238-252$.

Wilson, S., Liber, O., Johnson, M., Beauvoir, P., Sharples, P., \& Milligan, C. 2009. Personal learning environments: Challenging the dominant design of educational systems. Journal of e-Learning and Knowledge Society, 3(2), 27-38.

Wold, H. (1982). Systems under indirect observation using PLS. In C. Forell (Ed.), A second generation of multivariate analysis (Vol. 1, pp. 325-347). New York: Praege

Wong, A. (2016). Student Satisfaction and School Reputation: The Moderating Role of Student Loyalty and School Image. Journal of Marketing and HR, 2(1), 113-125.

Wu, C.H., Parker, S.K., \& De Jong, J.P. (2014). Need for cognition as an antecedent of individual innovation behavior. Journal of Management, 40(6), 1511-1534. 
Arquero, J. L., del Barrio-García, S., \& Romero-Frías, E. (2016). What Drives Students' Loyalty-Formation in Social Media Learning Within a Personal Learning Environment Approach? The Moderating Role of Need for Cognition. Journal of Educational Computing Research, Volume: 55 issue: 4, page(s): 495-525

https://doi.org/10.1177/0735633116672056 Preprint for research purposes.

Please refer to the journal's page for the final version of the paper

Xu, C., Ryan, S., Prybutok, V., \& Wen, C. (2012). It is not for fun: An examination of social network site usage. Information \& Management, 49(5), 210-217.

Zeithaml, V.A., Berry, L.L., \& Parasuraman, S. (1996). The behavioral of service quality. Journal of Marketing, 60(2), 31-46.

Zhang, Y., \& Buda, R. (1999). Moderating effects of need for cognition on responses to positively versus negatively frame advertising messages. Journal of Advertising, 28(2), 1-15. 
Arquero, J. L., del Barrio-García, S., \& Romero-Frías, E. (2016). What Drives Students' Loyalty-Formation in Social Media Learning Within a Personal Learning Environment Approach? The Moderating Role of Need for Cognition. Journal of Educational Computing Research, Volume: 55 issue: 4, page(s): 495-525

https://doi.org/10.1177/0735633116672056 Preprint for research purposes.

Please refer to the journal's page for the final version of the paper

\section{Annex. Scales and Items}

\begin{tabular}{|c|c|}
\hline $\begin{array}{l}\text { Attitude } \\
\text { Toward Using }\end{array}$ & $\begin{array}{l}\text { After using the Web } 2.0 \text { tools employed on this course, I think that... (1: } \\
\text { strongly disagree; 7: strongly agree) }\end{array}$ \\
\hline ATU1 & ...working with them is comfortable \\
\hline ATU2 & ...working with them saves me time \\
\hline ATU3 & ...working with them is safe \\
\hline $\begin{array}{l}\text { Students } \\
\text { Loyalty }\end{array}$ & $\begin{array}{l}\text { After getting to know the Web } 2.0 \text { tools employed on this course... (1: strongly } \\
\text { disagree; 7: strongly agree) }\end{array}$ \\
\hline WIR1 & ... I will make positive comment about them to other people \\
\hline WIR2 & ... I will recommend them to other people asking me for advice \\
\hline WIR3 & ... I will encourage my classmates to use them \\
\hline BIU1 & ... I will use them again \\
\hline $\begin{array}{l}\text { Learning } \\
\text { Satisfaction }\end{array}$ & $\begin{array}{l}\text { In general terms, after my experience of using the Web } 2.0 \text { tools employed on } \\
\text { this course... }\end{array}$ \\
\hline SAT1 & I feel: (1) very dissatisfied ... (7) very satisfied \\
\hline SAT2 & I feel: (1) very upset ... (7) very happy \\
\hline $\begin{array}{l}\text { Need for } \\
\text { Cognition }\end{array}$ & $\begin{array}{l}\text { Please indicate the extent to which you agree with the following statements (1: } \\
\text { strongly disagree; 7: strongly agree) }\end{array}$ \\
\hline NFC1 & I prefer complex problems to simple ones \\
\hline NFC2 & Thinking is fun \\
\hline NFC3 & I derive satisfaction from thinking reflectively for hours on end \\
\hline $\mathrm{NFC4}$ & I only think as hard as I have to \\
\hline NFC5 & $\begin{array}{l}\text { I would prefer a task that is intellectual, difficult and important to one that is } \\
\text { somewhat important but does not require much thought }\end{array}$ \\
\hline
\end{tabular}


Arquero, J. L., del Barrio-García, S., \& Romero-Frías, E. (2016). What Drives Students' Loyalty-Formation in Social Media Learning Within a Personal Learning Environment Approach? The Moderating Role of Need for Cognition. Journal of Educational Computing Research, Volume: 55 issue: 4, page(s): 495-525

https://doi.org/10.1177/0735633116672056 Preprint for research purposes.

Please refer to the journal's page for the final version of the paper

Table 1: Analysis of the psychometric properties of the scales (standardized solution)

\begin{tabular}{|c|c|c|c|c|c|c|c|c|c|}
\hline \multirow{2}{*}{$\begin{array}{l}\text { Observed } \\
\text { Variables }\end{array}$} & \multirow{2}{*}{$\begin{array}{c}\text { Latent } \\
\text { Variables }\end{array}$} & \multicolumn{2}{|c|}{$H I G H \_N F C$} & \multicolumn{2}{|c|}{$L O W \_N F C$} & \multicolumn{2}{|c|}{$A V E$} & \multicolumn{2}{|c|}{$C R$} \\
\hline & & Loadings & t-value & Loadings & t-value & $\begin{array}{c}\text { HIGH- } \\
\text { NFC }\end{array}$ & $\begin{array}{c}\text { LOW- } \\
\text { NFC }\end{array}$ & $\begin{array}{c}\text { HIGH- } \\
\text { NFC }\end{array}$ & $\begin{array}{c}\text { LOW- } \\
\text { NFC }\end{array}$ \\
\hline ATU1 & \multirow[t]{2}{*}{ ATU } & .89 & 35.78 & .93 & 57.39 & \multirow[t]{2}{*}{.76} & \multirow[t]{2}{*}{.82} & \multirow[t]{2}{*}{.86} & \multirow[t]{2}{*}{.90} \\
\hline ATU2 & & .85 & 17.81 & .88 & 17.85 & & & & \\
\hline SAT1 & \multirow[t]{2}{*}{ SAT } & .92 & 63.99 & .91 & 37.21 & \multirow[t]{2}{*}{.84} & \multirow[t]{2}{*}{.83} & \multirow[t]{2}{*}{.91} & \multirow[t]{2}{*}{.91} \\
\hline SAT2 & & .91 & 54.95 & .90 & 27.65 & & & & \\
\hline WIR1 & \multirow[t]{3}{*}{ WIR } & .90 & 51.16 & .93 & 53.88 & \multirow[t]{3}{*}{.83} & \multirow[t]{3}{*}{.86} & \multirow[t]{3}{*}{.93} & \multirow[t]{3}{*}{.95} \\
\hline WIR2 & & .92 & 53.17 & .93 & 47.25 & & & & \\
\hline WIR3 & & .91 & 49.30 & .91 & 48.80 & & & & \\
\hline BIU1 & BIU & 1.00 & --- & 1.00 & --- & 1.00 & 1.00 & 1.00 & 1.00 \\
\hline
\end{tabular}

ATU: Attitude Toward Using, SAT: Learning Satisfaction, WIR: Willingness to Recommend, BIU: Behavioral Intention to Use 
Arquero, J. L., del Barrio-García, S., \& Romero-Frías, E. (2016). What Drives Students' Loyalty-Formation in Social Media Learning Within a Personal Learning Environment Approach? The Moderating Role of Need for Cognition. Journal of Educational Computing Research, Volume: 55 issue: 4, page(s): 495-525

https://doi.org/10.1177/0735633116672056 Preprint for research purposes.

Please refer to the journal's page for the final version of the paper

Table 2: The heterotrait-monotrait (HTMT) ratio of correlations

\begin{tabular}{|c|c|c|c|c|}
\hline & ATU & SAT & BIU & WIR \\
\hline ATU & -- & & & \\
\hline SAT & 0.85 & -- & & \\
\hline BIU & 0.58 & 0.69 & -- & \\
\hline WIR & 0.68 & 0.82 & 0.76 & -- \\
\hline
\end{tabular}


Arquero, J. L., del Barrio-García, S., \& Romero-Frías, E. (2016). What Drives Students' Loyalty-Formation in Social Media Learning Within a Personal Learning Environment Approach? The Moderating Role of Need for Cognition. Journal of Educational Computing Research, Volume: 55 issue: 4, page(s): 495-525

https://doi.org/10.1177/0735633116672056 Preprint for research purposes.

Please refer to the journal's page for the final version of the paper

Table 3: Measurement invariance assessment test (MICOM)

\begin{tabular}{|c|c|c|c|c|}
\hline & $\begin{array}{c}\text { Original } \\
\text { Correlation }\end{array}$ & $\begin{array}{c}\text { Correlation } \\
\text { Permutation Mean }\end{array}$ & $5.0 \%$ & Permutation p-values \\
\hline ATU & 1.000 & .998 & .994 & .686 \\
\hline WIR & 1.000 & 1.000 & 1.000 & .825 \\
\hline BIU & 1.000 & 1.000 & 1.000 & .483 \\
\hline LOY & 1.000 & 1.000 & 1.000 & .575 \\
\hline SAT & 1.000 & 1.000 & .999 & .907 \\
\hline
\end{tabular}

MICOM Test returns confidence intervals that allow determining if a construct has a correlation in Group High_NFC and Group Low_NFC that is significantly lower than one. If this is not the case, the construct does not differ much in both groups and compositional invariance has been established (Henseler et al., 2016) 
Arquero, J. L., del Barrio-García, S., \& Romero-Frías, E. (2016). What Drives Students' Loyalty-Formation in Social Media Learning Within a Personal Learning Environment Approach? The Moderating Role of Need for Cognition. Journal of Educational Computing Research, Volume: 55 issue: 4, page(s): 495-525

https://doi.org/10.1177/0735633116672056 Preprint for research purposes.

Please refer to the journal's page for the final version of the paper

Table 4: Multigroup invariance analysis results (PLS-MGA)

\begin{tabular}{|c|c|c|c|c|}
\hline Relationships & $\begin{array}{c}\text { Coefficients } \\
\text { HIGH_NFC }\end{array}$ & $\begin{array}{c}\text { Coefficients } \\
\text { LOW_NFC }\end{array}$ & $\begin{array}{c}\text { Path coefficients } \\
\text { difference }\end{array}$ & $p_{\text {-value }}^{\dagger}$ \\
\hline ATU $\rightarrow$ LOY & .06 & .37 & .310 & $.975^{*}$ \\
\hline ATU $\rightarrow$ SAT & .57 & .79 & .214 & $.995^{* *}$ \\
\hline LOY $\rightarrow$ WIR & .98 & .98 & .004 & .769 \\
\hline LOY $\rightarrow$ BIU & .82 & .86 & .033 & .774 \\
\hline SAT $\rightarrow$ LOY & .70 & .39 & .308 & $.019^{*}$ \\
\hline
\end{tabular}

Note: This method is a non-parametric significance test for the difference of group-specific results that builds on PLS bootstrapping results. A result is significant at the 5\% probability of error level, if the pvalue is smaller than .05 or larger than .95 for a certain difference of group-specific path coefficients.

$\dagger * * \mathrm{p}<.01 ; * \mathrm{p}<.05$ 
Arquero, J. L., del Barrio-García, S., \& Romero-Frías, E. (2016). What Drives Students' Loyalty-Formation in Social Media Learning Within a Personal Learning Environment Approach? The Moderating Role of Need for Cognition. Journal of Educational Computing Research, Volume: 55 issue: 4, page(s): 495-525

https://doi.org/10.1177/0735633116672056 Preprint for research purposes.

Please refer to the journal's page for the final version of the paper

Table 5: Standardized Total Effects

\begin{tabular}{|l|c|c|c|c|}
\hline \multicolumn{1}{|c|}{ Relationships } & $\begin{array}{c}\text { Total effects } \\
\text { HIGH_NFC }\end{array}$ & $\begin{array}{c}\text { Total effects } \\
\text { LOW_NFC }\end{array}$ & Total effects differences & $p$-value \\
\hline ATU $\rightarrow$ WIR & .45 & .67 & .215 & $.987^{* *}$ \\
\hline ATU $\rightarrow$ BIU & .38 & .58 & .202 & $.984^{*}$ \\
\hline ATU $\rightarrow$ LOY & .46 & .68 & .217 & $.988^{* *}$ \\
\hline ATU $\rightarrow$ SAT & .57 & .79 & .214 & $.995^{* *}$ \\
\hline LOY $\rightarrow$ WIR & .98 & .98 & .004 & .769 \\
\hline LOY $\rightarrow$ BIU & .82 & .86 & .033 & .774 \\
\hline SAT $\rightarrow$ WIR & .68 & .38 & .300 & $.020^{*}$ \\
\hline SAT $\rightarrow$ BIU & .58 & .33 & .242 & $.032^{*}$ \\
\hline SAT $\rightarrow$ LOY & .70 & .39 & .308 & $.019^{*}$ \\
\hline
\end{tabular}

$\dagger * * \mathrm{p}<.01 ; * \mathrm{p}<.05$ 
Arquero, J. L., del Barrio-García, S., \& Romero-Frías, E. (2016). What Drives Students' Loyalty-Formation in Social Media Learning Within a Personal Learning Environment Approach? The Moderating Role of Need for Cognition. Journal of Educational Computing Research, Volume: 55 issue: 4, page(s): 495-525

https://doi.org/10.1177/0735633116672056 Preprint for research purposes.

Please refer to the journal's page for the final version of the paper

Table 6. Perceived impact of students' experience

\begin{tabular}{|c|c|c|c|c|}
\hline & Groups & Mean & $\begin{array}{c}\text { Standard } \\
\text { Deviation }\end{array}$ & p-value \\
\hline \multirow{2}{*}{ Attitude Toward Using } & Low NFC & 3.89 & .72 & \multirow{2}{*}{.02} \\
\cline { 2 - 4 } & High NFC & 4.13 & .63 & .76 \\
\hline \multirow{2}{*}{ Learning Satisfaction } & Low NFC & 3.87 & .00 \\
\cline { 2 - 4 } $\begin{array}{c}\text { Behavioral Intention to } \\
\text { Use }\end{array}$ & High NFC & 4.14 & .66 & \multirow{2}{*}{.00} \\
\cline { 1 - 4 } & Low NFC & 3.95 & .97 & \multirow{2}{*}{.00} \\
\hline \multirow{2}{*}{$\begin{array}{c}\text { Willingness to } \\
\text { Recommend }\end{array}$} & High NFC & 4.32 & .80 & .82 \\
\cline { 2 - 4 } & Low NFC & 3.80 & .75 & \\
\hline
\end{tabular}


Arquero, J. L., del Barrio-García, S., \& Romero-Frías, E. (2016). What Drives Students' Loyalty-Formation in Social Media Learning Within a Personal Learning Environment Approach? The Moderating Role of Need for Cognition. Journal of Educational Computing Research, Volume: 55 issue: 4, page(s): 495-525

https://doi.org/10.1177/0735633116672056 Preprint for research purposes.

Please refer to the journal's page for the final version of the paper

Figure 1: Proposed theoretical model of student loyalty-formation

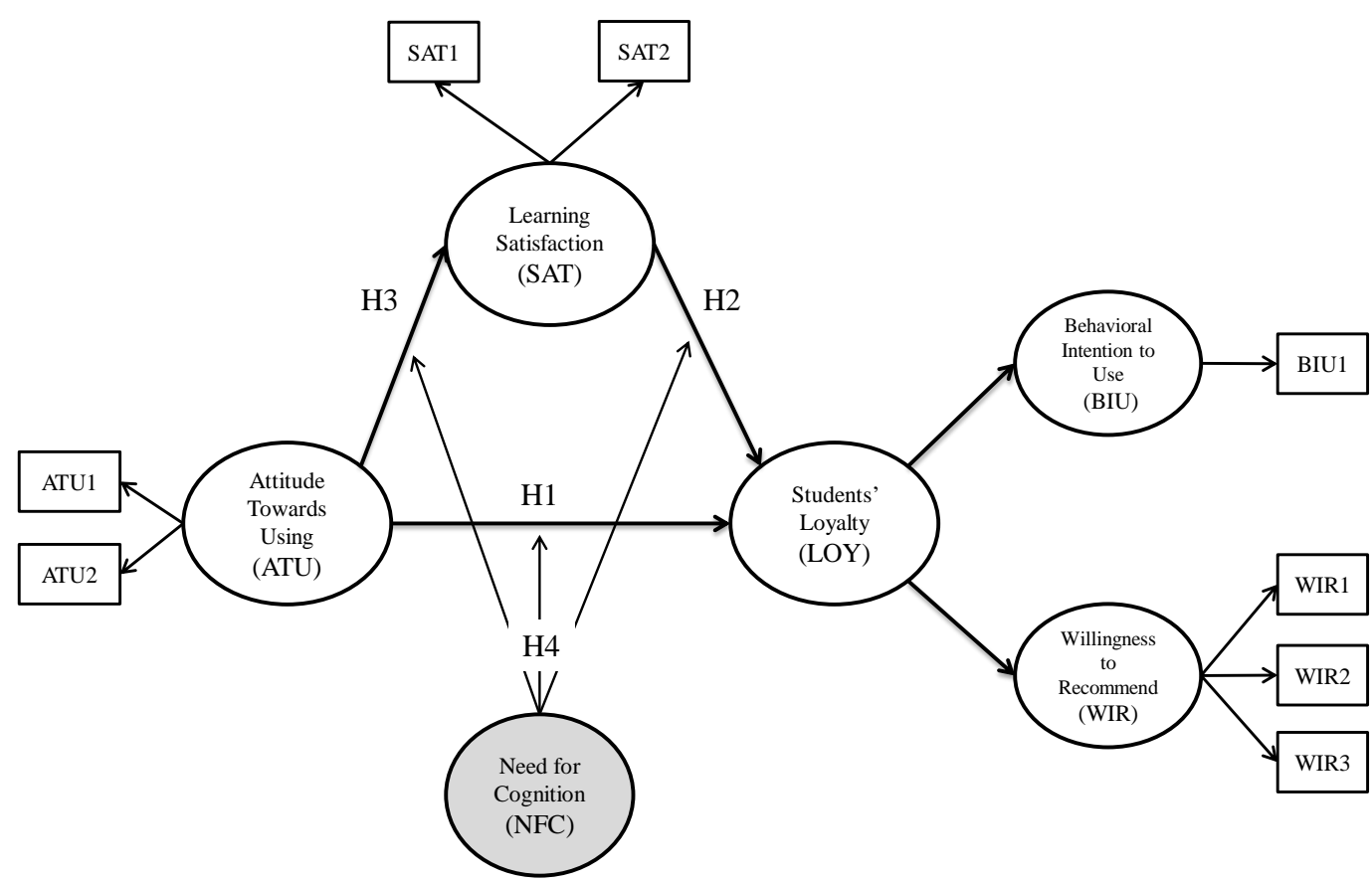

Figure 2: Estimated structural model - inner model (standardized solution)

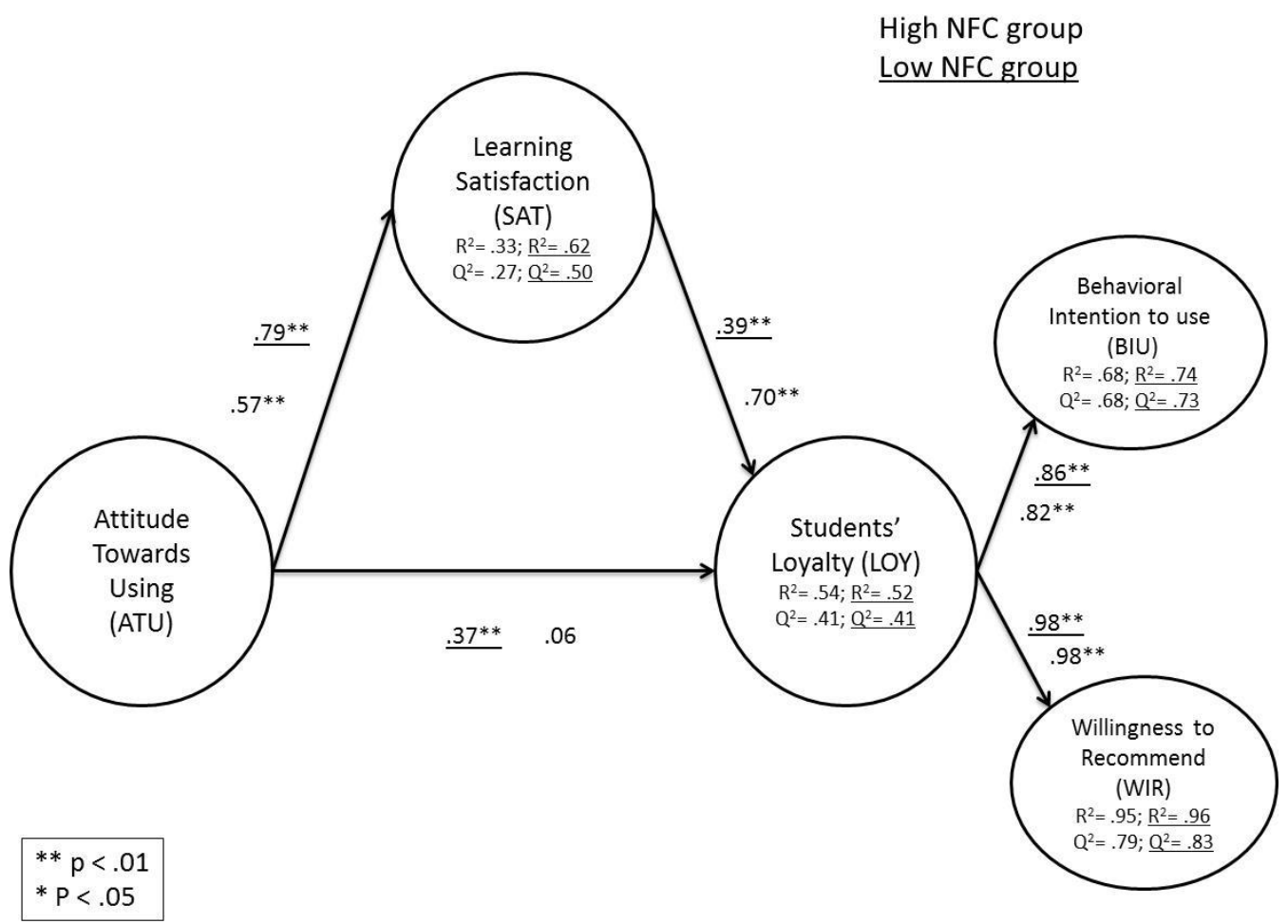

